\title{
Antiproliferative activity and apoptosis-inducing mechanism of constituents from Toona sinensis on human cancer cells
}

Shengjie Yang ${ }^{1,2}$, Qi Zhao ${ }^{1,2}$, Hongmei Xiang ${ }^{1,2}$, Minjie Liu ${ }^{1,2}$, Qiuyun Zhang ${ }^{1,2}$, Wei Xue ${ }^{1,2}$, Baoan Song ${ }^{1,2^{*}}$ and Song Yang ${ }^{1,2^{*}}$

\begin{abstract}
Background: Natural products, including plants, microorganisms and marines, have been considered as valuable sources for anticancer drug discovery. Many Chinese herbs have been discovered to be potential sources of antitumor drugs.

Methods: In the present study, we investigated the antitumor efficacy of the compounds isolated from Toona sinensis, an important herbal medicine. The inhibitory activities of these compounds were investigated on MGC-803, PC3, A549, MCF-7, and NIH3T3 cells in vitro by MTT assay. The mechanism of the antitumor action of active compounds was investigated through AO/EB staining, Hoechst 33258 staining, TUNEL assay, flow cytometry analysis, and western blotting analysis.

Results: Fifteen compounds were isolated from the roots of Toona sinensis. Betulonic acid (BTA) and 3-oxours-12en-28-oic acid (OEA) isolated from the plant inhibited the proliferation of MGC-803 and PC3 cells, with $\mathrm{IC}_{50}$ values of $17.7 \mu \mathrm{M}$ and $13.6 \mu \mathrm{M}, 26.5 \mu \mathrm{M}$ and $21.9 \mu \mathrm{M}$, respectively. Both could lead to cell apoptosis, and apoptosis ratios reached $27.3 \%$ and $24.5 \%$ in MGC-803 cells at $72 \mathrm{~h}$ after treatment at $20 \mu \mathrm{M}$, respectively. Moreover, the study of cancer cell apoptotic signaling pathway indicated that both of them could induce cancer cell apoptosis through the mitochondrial pathway, involving the expressions of p53, Bax, caspase 9 and caspase 3.

Conclusions: The study shows that most of the compounds obtained from Toona sinensis could inhibit the growth of human cancer cells. Furthermore, BTA and OEA exhibited potent antitumor activities via induction of cancer cell apoptosis.
\end{abstract}

Keywords: Toona sinensis, Antiproliferation, Apoptosis, Pathway

\section{Background}

Among the conventional antitumor cytotoxic chemotherapies, many compounds are derived from natural products [1-3]. Over $60 \%$ of the current anticancer drugs have their origin in one way or another from natural sources $[4,5]$. Natural compounds had attracted considerable attention

\footnotetext{
* Correspondence: basong@gzu.edu.cn; jhzx.msm@gmail.com

'State-Local Joint Laboratory for Comprehensive Utilization of Biomass, State Key Laboratory Breeding Base of Green Pesticide and Agricultural Bioengineering, Key Laboratory of Green Pesticide and Agricultural Bioengineering, Ministry of Education, Guizhou University, Guiyang 550025, P. R. China

${ }^{2} \mathrm{Ctr}$ for R\&D of Fine Chemicals, Guizhou University, Huaxi St, Guiyang 550025, China
}

\section{Biomed Central}

(c) 2013 Yang et al.; licensee BioMed Central Ltd. This is an Open Access article distributed under the terms of the Creative Commons Attribution License (http://creativecommons.org/licenses/by/2.0), which permits unrestricted use, distribution, and reproduction in any medium, provided the original work is properly cited. peutics [6,7]. As cancer cells have evolved multiple mechanisms to resist the induction of programmed cell death (apoptosis), the modulation of apoptosis signaling pathways by natural compounds have been demonstrated to constitute a key event in these antitumor activities [8,9]. Toona sinensis, an important herb medicine, belongs to the Meliaceae family which comprises approximately 50 genera and 1400 species throughout the world [10], and is widely distributed in China except Xinjiang and Inner Mongolia Autonomous Regions. The objective of present study was to evaluate the potency of the components from the plant for growth inhibiting of human cancer cell lines and to 
Table 1 Antitumor activities of the isolated compounds on the proliferation of different cell lines

\begin{tabular}{|c|c|c|c|c|c|}
\hline \multirow[t]{2}{*}{ Compound } & \multicolumn{5}{|c|}{ Inhibitory Rate for Different Cell Lines $\left(\%\right.$, mean \pm SD) ${ }^{a}$} \\
\hline & MGC-803 & PC3 & A549 & MCF-7 & NIH3T3 \\
\hline$\beta$-sitosterol (1) & $23.5 \pm 2.1$ & $16.5 \pm 2.3$ & $12.6 \pm 3.1$ & $18.9 \pm 1.7$ & $5.6 \pm 2.4$ \\
\hline a-Amyrin (2) & $23.5 \pm 5.4$ & $17.8 \pm 4.9$ & $7.8 \pm 1.5$ & $10.4 \pm 1.8$ & $7.6 \pm 4.5$ \\
\hline Daucosterol (3) & $12.3 \pm 4.1$ & $9.8 \pm 3.6$ & $4.5 \pm 1.8$ & $7.2 \pm 5.2$ & $4.3 \pm 2.3$ \\
\hline Quercetin (4) & $17.2 \pm 1.7$ & $22.7 \pm 1.4$ & $16.9 \pm 2.4$ & $42.2 \pm 1.6$ & $4.2 \pm 2.5$ \\
\hline (+)-Catechin (5) & $52.1 \pm 5.7$ & $49.6 \pm 2.3$ & $45.3 \pm 3.2$ & $37.6 \pm 3.9$ & $28.9 \pm 4.3$ \\
\hline (-)-Epicatchin (6) & $45.5 \pm 4.1$ & $50.6 \pm 1.6$ & $47.1 \pm 1.1$ & $43.2 \pm 3.6$ & $22.5 \pm 3.8$ \\
\hline Kampferol (7) & $58.2 \pm 3.0$ & $46.1 \pm 5.9$ & $42.0 \pm 2.2$ & $39.2 \pm 6.8$ & $11.1 \pm 6.7$ \\
\hline 3-Oxours-12-en-28-oic acid (8) & $45.2 \pm 2.0$ & $42.5 \pm 1.4$ & $35.9 \pm 0.8$ & $37.2 \pm 1.5$ & $23.6 \pm 1.3$ \\
\hline Ursolic acid (9) & $52.1 \pm 2.2$ & $55.6 \pm 2.4$ & $37.6 \pm 1.7$ & $47.8 \pm 1.2$ & $21.7 \pm 4.9$ \\
\hline Betulonic acid (10) & $56.1 \pm 2.6$ & $63.4 \pm 4.2$ & $35.2 \pm 2.4$ & $51.2 \pm 4.4$ & $22.1 \pm 6.2$ \\
\hline Gallic acid (11) & $55.7 \pm 1.9$ & $40.2 \pm 4.2$ & $46.3 \pm 3.6$ & $33.1 \pm 1.4$ & $13.6 \pm 2.2$ \\
\hline Betulinic acid (13) & $36.9 \pm 1.6$ & $23.6 \pm 3.4$ & $33.5 \pm 2.3$ & $41.6 \pm 3.7$ & $23.4 \pm 2.9$ \\
\hline ADM & $92.1 \pm 1.3$ & $93.4 \pm 2.6$ & $96.2 \pm 0.8$ & $91.1 \pm 2.2$ & $99.4 \pm 0.4$ \\
\hline
\end{tabular}

Note: ${ }^{\text {a }}$ Inhibitory percentage of cells treated with each compound $20 \mu \mathrm{mol} / \mathrm{L}$ for $72 \mathrm{~h}$ and SD $=$ standard deviation.

study their antitumor mechanism. Fifteen compounds were isolated from the plant, and these compounds were bioassayed on human gastric cancer cell line MGC-803, prostatic cancer cell line PC3, lung cancer cell line A549, breast cancer cell line MCF-7, and mouse embryonic fibroblast cell line NIH3T3 in vitro by MTT assay. Interestingly, it was found that betulonic acid (BTA) and 3-oxours-12-en28-oic acid (OEA) had the potent inhibitory activities against MGC-803 and PC3 cell lines, and were less toxic on normal cells than on the investigated cancer cell lines. Also, BTA and OEA are betulinic acid (BA) and ursolic acid (UA) derivatives, respectively. BA and UA are naturally occurring pentacyclic triterpenoids which are widely distributed in the plant kingdom $[11,12]$. It was found that BA could inhibit growth of cancer cells $[13,14]$, without affecting normal cells $[15,16]$, and it was a highly selective growth inhibitor of human melanoma, neuroectodermal and malignant tumor cells [17]. UA has also been reported to show significant cytotoxicity against some tumor cell lines [13,18-21]. There are a few reports on the anticancer effects of BTA and OEA on various tumor cells recently. Some studies have shown that BTA could inhibit the growth of various types of human tumor cell lines, including SGC-7901, HepG-2 [22], LNCaP, and DU-145 [23] cells. In 1999, Min et al. found that OEA possessed antitumor activity on A549, SK-OV-3, SK-MEL-2, XF498, and HCT15 cells, with low $\mathrm{IC}_{50}$ values $(<5 \mu \mathrm{g} / \mathrm{mL})$ [18]. However, no report was found on the antitumor mechanism of the two compounds. Thus, the mechanism of action needs to be further clarified. Further investigation of BTA and OEA was carried out on MGC-803 and PC3 cells, and experimental results of fluorescent staining and flow cytometry analysis indicated that the two compounds could induce cell apoptosis. In addition, the mechanism underlying apoptosis of BTA and OEA was also investigated in this study. To the best of our knowledge, this is the first report on apoptosis inducing of BTA and OEA in MGC-803 and PC3 cells.

\section{Methods}

Plant material

Fresh samples of Toona sinensis were collected from Bijie, Guizhou Province in China, in August 2011. Prof. Qingde Long, Department of Medicine, Guiyang Medical University, identified the plant material. A voucher specimen was deposited at Guiyang Medical University, Guiyang, China.

\section{Cell culture}

MGC-803, PC3, A549. MCF-7, and NIH3T3 cell lines were obtained from the Institute of Biochemistry and Cell Biology, China Academy of Science. MGC-803 is human gastric cancer cell line, PC3 is prostatic cancer cell line, A549 is lung cancer cell line, MCF-7 is breast cancer cell line, and NIH3T3 is mouse embryonic fibroblast cell line. The entire cancer cell lines were maintained in the RPMI 1640 medium and NIH3T3 was maintained in the DMEM medium. They were supplemented with $10 \%$ heat-inactivated fetal bovine serum (FBS) in a humidified atmosphere of $5 \% \mathrm{CO}_{2}$ at $37^{\circ} \mathrm{C}$. All cell lines were maintained at $37^{\circ} \mathrm{C}$ in a humidified $5 \%$ carbon dioxide and $95 \%$ air incubator. 


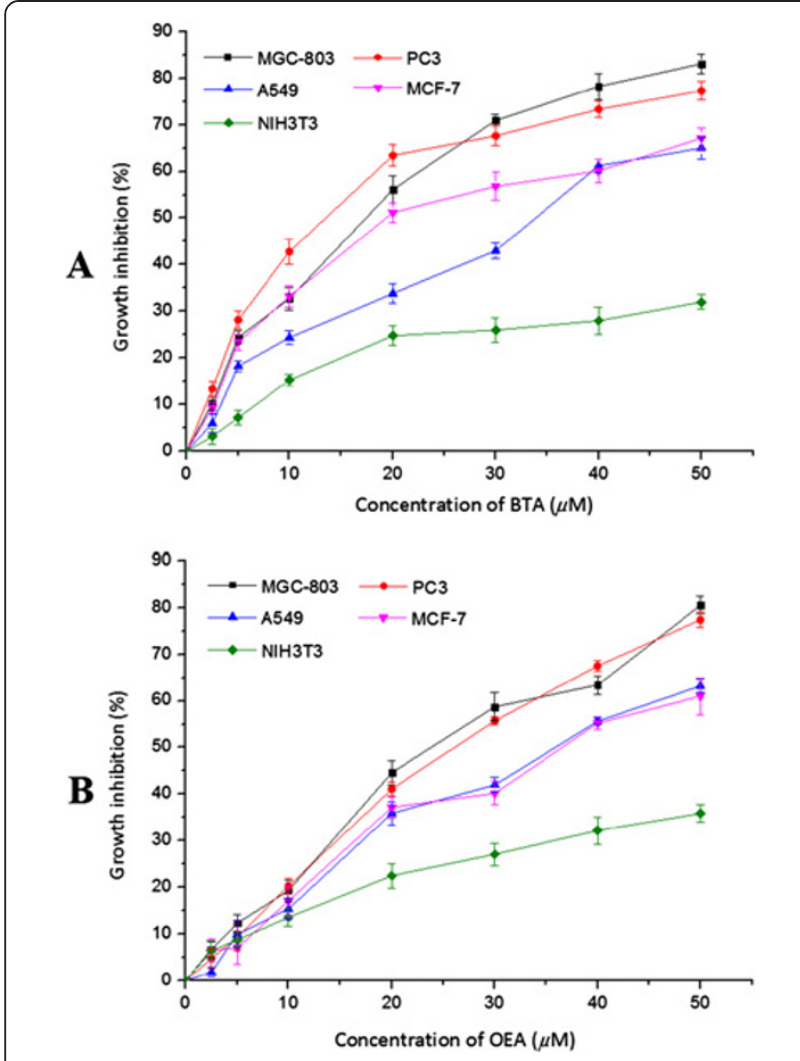

Figure 1 Effect of BTA and OEA on proliferation of tumor cells. Data are presented as means $\pm S D, n=4$.

\section{MTT assays}

The antitumor activities of the compounds were determined by MTT assay. All tested compounds were dissolved in DMSO and subsequently diluted in the culture medium before treatment of the cultured cells. When the cells were 80$90 \%$ confluent, they were harvested by treatment with a solution containing $0.25 \%$ trypsin, thoroughly washed and resuspended in supplemented growth medium. Cells $\left(1 \times 10^{4} /\right.$ well $)$ were plated in $100 \mu \mathrm{L}$ of medium/well in 96-well plate. After incubations overnight, the cells were treated with different concentrations of extracts or compounds for $72 \mathrm{~h}$. Thereafter, $100 \mu \mathrm{L}$ of MTT (Beyotime Co., Jiangsu, China) solution was added to each well and then incubated for $4 \mathrm{~h}$. The colored MTT-formazan crystals which were produced from MTT were dissolved in SDS for $12 \mathrm{~h}$. And then the OD values were measured at $595 \mathrm{~nm}$ with a microplate reader (BIO-RAD, model 680), which is directly proportional to the number of living cells in culture [24-26].

\section{AO/EB staining}

The active compounds were investigated for apoptotic activity by AO/EB staining. When the cells were $80-90 \%$ confluent, they were harvested by treatment with a solution containing $0.25 \%$ trypsin, thoroughly washed and resuspended in supplemented growth medium. The cells were seeded in 6-well tissue culture plates $\left(5 \times 10^{4}\right.$ cell $/ \mathrm{mL}, 0.6$ $\mathrm{mL} /$ well). After incubations overnight, the medium was removed and replaced with fresh medium plus 10\% FBS and then supplemented with compounds $(20 \mu \mathrm{mol} / \mathrm{L})$. After the treatment period, $20 \mu \mathrm{L}$ of the AO/EB dye mix (Beyotime Co., Shanghai, China) were added to each well, and the apoptotic cells were viewed and counted under the fluorescent microscope (OLYMPUS Co., Tokyo Met, Japan) $[27,28]$.

\section{Hoechst 33258 staining}

Morphological assessment of apoptotic cells was performed using Hoechst 33258 staining method. The cells were seeded in 6-well tissue culture plates $\left(5 \times 10^{4} \mathrm{cell} /\right.$ $\mathrm{mL}, 0.6 \mathrm{~mL} /$ well). After incubations overnight, the medium was removed and replaced with fresh medium plus $10 \%$ FBS and then supplemented with compounds $(20 \mu \mathrm{mol} / \mathrm{L})$ for a certain range of treatment time. The culture medium containing compounds was removed, and the cells were fixed in 4\% paraformaldehyde for $10 \mathrm{~min}$. The cells were washed twice with PBS, and were consequently stained with $0.5 \mathrm{~mL}$ of Hoechst 33258 staining (Beyotime Co., Jiangsu, China) for $5 \mathrm{~min}$. The stained nuclei were washed twice with PBS, and were consequently observed under an IX71SIF-3 fluorescence microscope at $350 \mathrm{~nm}$ excitation and $460 \mathrm{~nm}$ emissions [29].

\section{TUNEL assay}

The cells $\left(5 \times 10^{4}\right.$ cell $/ \mathrm{mL}, 0.6 \mathrm{~mL} /$ well $)$ were seeded in 6well tissue culture plates. Following incubation, the medium was removed and replaced with fresh medium plus $10 \%$ FBS and then supplemented with compounds $(20 \mu \mathrm{mol} / \mathrm{L})$. TUNEL assays were performed using a colorimetric TUNEL apoptosis assay kit according to the manufacturer's instructions. (1) After the treatment period, cells were washed with $1 \times \mathrm{PBS}$ and fixed in $4 \%$ paraformaldehyde for $40 \mathrm{~min}$. The cells were washed once with PBS, and were consequently permeabilized with immunol staining wash buffer for 2 min on ice. (2) The cells were rewashed once with $\mathrm{PBS}$, and were consequently incubated in $0.3 \% \mathrm{H}_{2} \mathrm{O}_{2}$ in methanol at room temperature for $20 \mathrm{~min}$ to inactivate the endogenous peroxidases, after which the cells were washed thrice with PBS. (3) The cells were incubated with $2 \mu \mathrm{L}$ of TdT-enzyme and $48 \mu \mathrm{L}$ of Biotin-dUTP per specimen for $60 \mathrm{~min}$ at $37^{\circ} \mathrm{C}$. The cells were terminated for $10 \mathrm{~min}$, and were consequently incubated with streptavidin-HRP (50 $\mu \mathrm{L}$ per specimen) conjugate diluted at 1:50 in sample diluent for $30 \mathrm{~min}$. (4) The cells were washed three times with PBS, and were consequently incubated with diaminobenzidine solution $(200 \mu \mathrm{L}$ per specimen) for $10 \mathrm{~min}$. At last, the cells were rewashed twice with PBS, and were consequently imaged under an XDS1B inverted biological microscope [30]. 


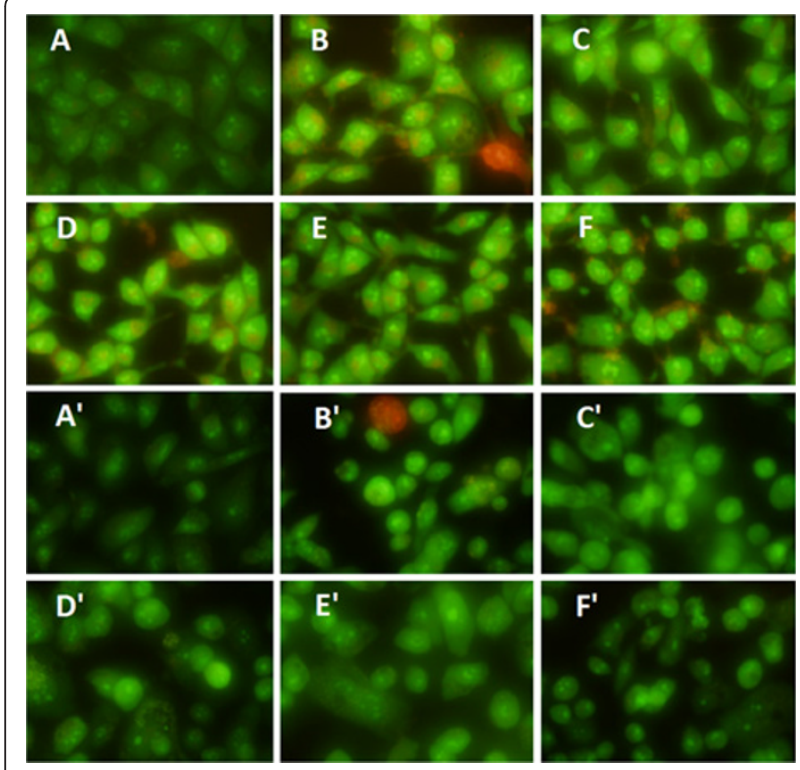

Figure 2 Results from the AO/EB staining. For MGC-803 cells group, A: negative control; $\mathbf{B}$ : positive control, treated with HCPT $(20 \mu \mathrm{M})$ for $48 \mathrm{~h}$; C, D: treated with BTA $(20 \mu \mathrm{M})$ for $24,48 \mathrm{~h}$; E, F: treated with OEA $(20 \mu \mathrm{M})$ for $24,48 \mathrm{~h}$. For PC3 cells group, $\mathbf{A}^{\prime}$ negative control; $\mathbf{B}^{\prime}$ : positive control, treated with HCPT $(20 \mu \mathrm{M})$ for 48 h; $\mathbf{C}^{\prime}, \mathbf{D}^{\prime}$ : treated with BTA $(20 \mu \mathrm{M})$ for $24,48 \mathrm{~h} ; \mathbf{E}^{\prime}, \mathbf{F}^{\prime}$ : treated with OEA $(20 \mu \mathrm{M})$ for $24,48 \mathrm{~h}$.

\section{Flow cytometry analysis}

Prepared MGC-803 cells $\left(1 \times 10^{6} / \mathrm{mL}\right)$ were washed twice with cold PBS and then re-suspended gently in $500 \mu \mathrm{L}$ binding buffer. Thereafter, cells were stained in 5 $\mu \mathrm{L}$ Annexin V-FITC and shaked well. Finally, $5 \mu \mathrm{L}$ PI was added to these cells and incubated for $20 \mathrm{~min}$ in a dark place, analyzed by FACS Calibur, Becton Dickinson $[31,32]$.

\section{Caspase 3 enzyme assay}

Cells were collected after treatment with BTA and OEA at $2.5,5$, and $10 \mu \mathrm{M}$ for $12 \mathrm{~h}$, respectively. Prepared MGC-803 cells $\left(1 \times 10^{6} / \mathrm{mL}, 5 \mathrm{ml}\right)$ were washed twice with cold PBS. Then, $100 \mu \mathrm{L}$ of lysis buffer was added to the cells for $25 \mathrm{~min}$ on ice and centrifuged at $16000 \mathrm{~g}$ for 15 min. $80 \mu \mathrm{L}$ of reaction buffer and $10 \mu \mathrm{L}$ of AcDEVED- $p$ NA were added to $10 \mu \mathrm{L}$ of supernatant liquid. After incubating at $37^{\circ} \mathrm{C}$ for $2-3 \mathrm{~h}$ in darkness, the absorbance was measured at $405 \mathrm{~nm}$, with the lysis buffer and reaction buffer as control

\section{Caspase 9 enzyme assay}

Cells were collected after treatment with BTA and OEA at $2.5,5$, and $10 \mu \mathrm{M}$ for $12 \mathrm{~h}$, respectively. Prepared MGC-803 cells $\left(1 \times 10^{6} / \mathrm{mL}, 5 \mathrm{ml}\right)$ were washed twice with cold PBS. Then, $100 \mu \mathrm{L}$ of lysis buffer was added to the cells for $25 \mathrm{~min}$ on ice and centrifuged at $16000 \mathrm{~g}$

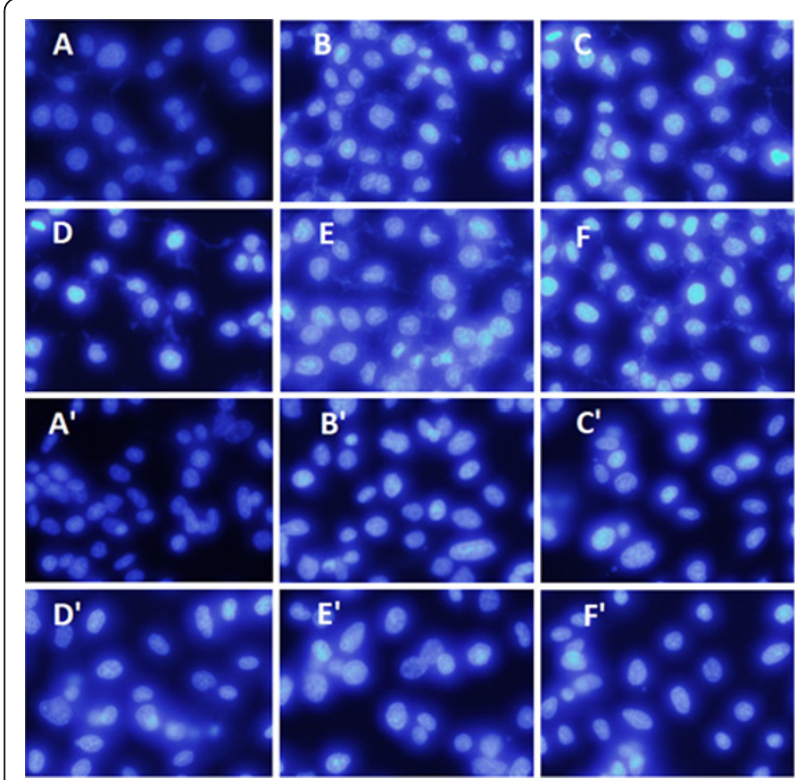

Figure 3 Results from the Hoechst 33258 staining. For MGC-803 cells group, A: negative control; B: positive control, treated with HCPT $(20 \mu \mathrm{M})$ for $48 \mathrm{~h}$; C, D: treated with BTA $(20 \mu \mathrm{M})$ for $24,48 \mathrm{~h}$; $\mathbf{E}$, F: treated with OEA $(20 \mu \mathrm{M})$ for $24,48 \mathrm{~h}$. For PC3 cells group, $\mathbf{A}^{\prime}$ : negative control; B': positive control, treated with HCPT $(20 \mu \mathrm{M})$ for 48 h; $\mathbf{C}^{\prime}, \mathbf{D}^{\prime}$ : treated with BTA $(20 \mu \mathrm{M})$ for 24,48 h; E', F': treated with OEA $(20 \mu \mathrm{M})$ for $24,48 \mathrm{~h}$.

for 15 min. $80 \mu \mathrm{L}$ of reaction buffer and $10 \mu \mathrm{L}$ of AcLEHD-pNA were added to $10 \mu \mathrm{L}$ of supernatant liquid. After incubating at $37^{\circ} \mathrm{C}$ for $2-3 \mathrm{~h}$ in darkness, the absorbance was measured at $405 \mathrm{~nm}$, with the lysis buffer and reaction buffer as control.

\section{Western botting analysis}

Cells were collected after treatment with BTA and OEA at $2.5,5$, and $10 \mu \mathrm{M}$ for $12 \mathrm{~h}$, respectively. Western blotting analysis was performed as previously described [33], using the following antibodies at dilutions of 1:500 to 1:1000: anti-p53, anti-Bax, and anti- $\beta$ actin (Cell signaling technology, Beverly, MA).

\section{Statistical analysis}

All statistical analyses were performed using SPSS 10.0, and the data were analyzed using one-way ANOVA. The mean separations were performed using the least significant difference method. Each experiment was performed in triplicate, and all experiments were run thrice and yielded similar results. Measurements from all the replicates were combined, and the treatment effects were analyzed.

\section{Results and discussion}

The roots of Toona sinensis collected from Guizhou province were studied, and fifteen compounds were isolated from the plants. The extraction and purification 


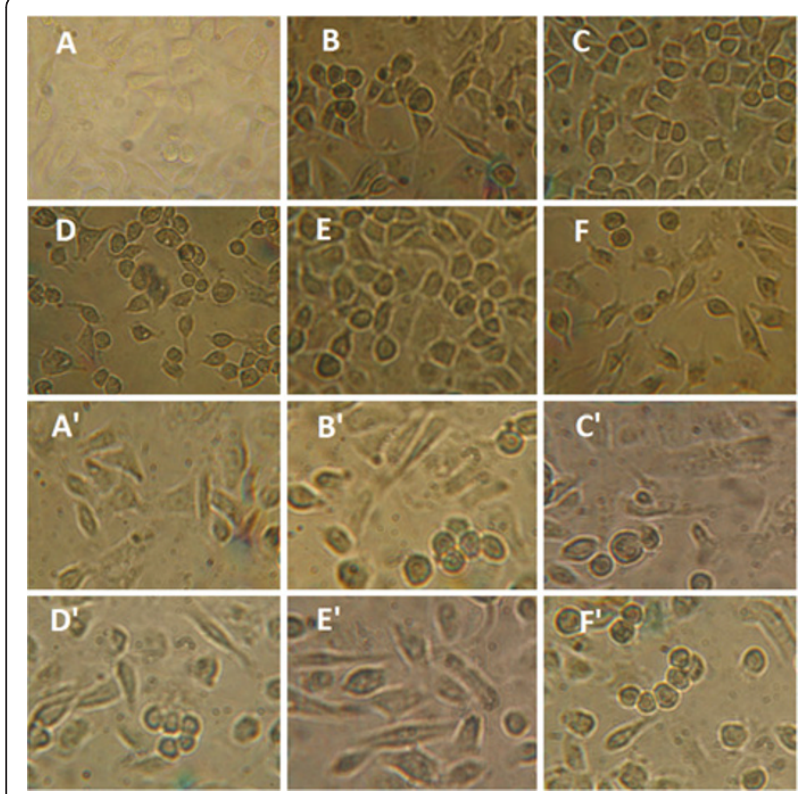

Figure 4 Results from the TUNEL assay. For MGC-803 cells group, A: negative control; B: positive control, treated with HCPT ( $20 \mu \mathrm{M})$ for 48 h; C, D: treated with BTA $(20 \mu \mathrm{M})$ for 24,48 h; E, F: treated with OEA $(20 \mu \mathrm{M})$ for $24,48 \mathrm{~h}$. For PC3 cells group, $\mathbf{A}^{\prime}$ : negative control; B': positive control, treated with HCPT $(20 \mu \mathrm{M})$ for $48 \mathrm{~h}$; $\mathbf{C}^{\prime}$, $\mathbf{D}^{\prime}$ : treated with BTA $(20 \mu \mathrm{M})$ for $24,48 \mathrm{~h} ; \mathbf{E}^{\prime}, \mathbf{F}^{\prime}$ : treated with OEA $(20 \mu \mathrm{M})$ for $24,48 \mathrm{~h}$.

process of the compounds from the plant and their NMR data are presented in Additional file 1.

The potential effect of the compounds from Toona sinensis was investigated on the viability of MGC-803, PC3, A549, MCF-7, and NIH3T3 cells by MTT assay, with ADM (Adriamycin) being used as the positive control and culture medium containing $0.1 \%$ DMSO used as the negative control. The inhibitory percentage of cancer cells was treated with $20 \mu \mathrm{mol} / \mathrm{L}$ of each compound for $72 \mathrm{~h}$. The results are summarized in Table 1 . It could be seen from Table 1 that both of BTA and OEA showed potent antitumor activities against MGC-803 and PC3 cell lines. The inhibitory ratios of BTA and OEA at $72 \mathrm{~h}$ after treatment were $56.1 \%$ and $45.2 \%$ against MGC-803 cells, $63.4 \%$ and $42.5 \%$ against PC3 cells, $22.1 \%$ and $23.6 \%$ against NIH3T3 normal cell line, respectively. In addition, BTA also had good activities against MCF-7 cells, with inhibitory ratio of $51.2 \%$. Thus, the two compounds were less toxic on normal cells than on the investigated cancer cell lines.

To best of our knowledge, the two compounds, BTA and OEA, were obtained from Toona sinensis for the first time. It was also found to have the greatest potency against the growth of human cancer cell lines and little toxic effect on NIH3T3 cells among the isolated constituents. Further experiments found that proliferation of these four cancer cells were significantly inhibited by

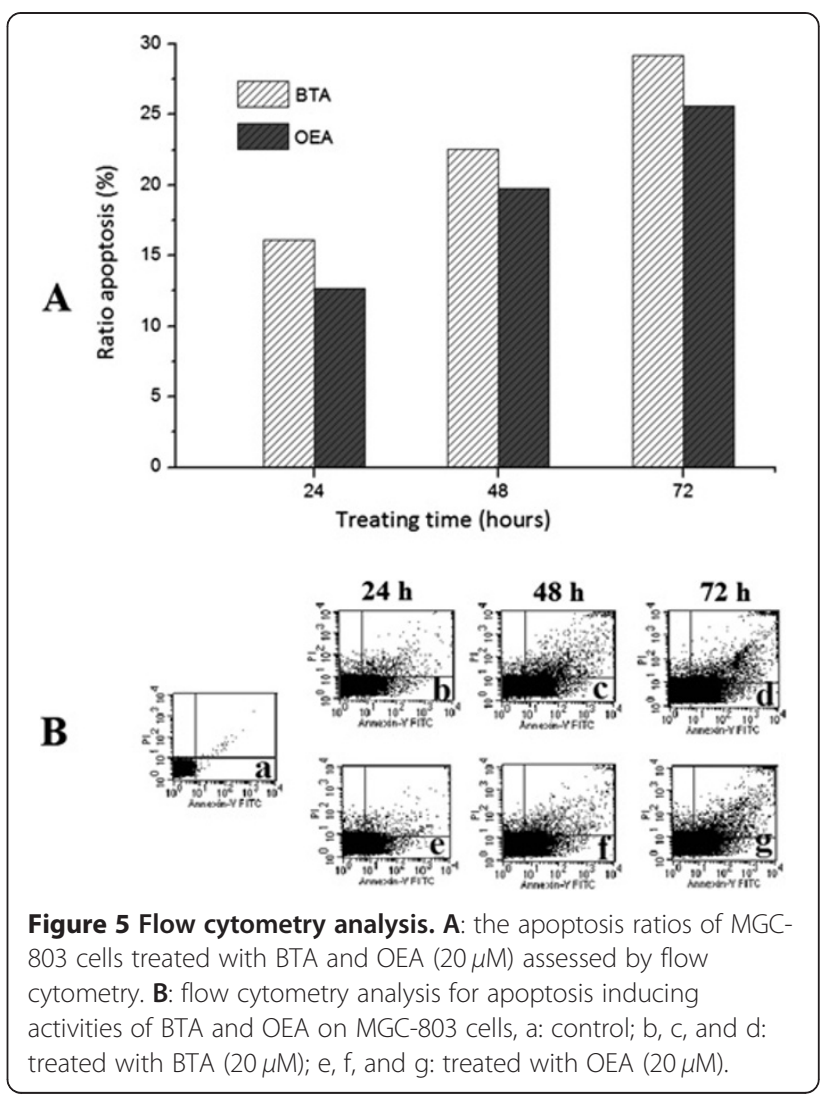

BTA and OEA in a concentration-dependent manner, as shown in Figure $1 \mathrm{~A}$ and $1 \mathrm{~B}$. The $\mathrm{IC}_{50}$ values of BTA and OEA on MGC-803 and PC3 cells were determined to be $17.7 \mu \mathrm{M}$ and $13.6 \mu \mathrm{M}, 26.5 \mu \mathrm{M}$ and $21.9 \mu \mathrm{M}$, respectively, all of which were lower than that on NIH3T3 cells $\left(\mathrm{IC}_{50}>50 \mu \mathrm{M}\right)$ by MTT assay. On this occasion, the two compounds were both less toxic on normal cells than on the investigated cancer cell lines and much selective to cancer cells.

Apoptosis is a physiological pattern of cell death characterized by morphological features and extensive DNA fragmentation [34]. Thus, to determine whether the grown inhibitory activities of BTA and OEA were related to the induction of apoptosis, the morphological changes of MGC-803 and PC3 cells were investigated using acridine orange/ethidium bromide $(\mathrm{AO} / \mathrm{EB})$ staining and Hoechst 33258 staining, and Terminal deoxynucleotidyl transferase dUTP nick end labeling (TUNEL) assay to confirm cell apoptosis. Moreover, the apoptosis ratios induced by BTA and OEA caused apoptosis in MGC803 cells were quantitatively assessed by flow cytometry (FCM). Interestingly, whether the cancer cell apoptosis by the two compounds was though the mitochondrial pathway was also studied.

$\mathrm{AO}$ is taken up by both viable and non-viable cells and emits green fluorescence if intercalated into double stranded nucleic acid (DNA), and EB is taken up only by 


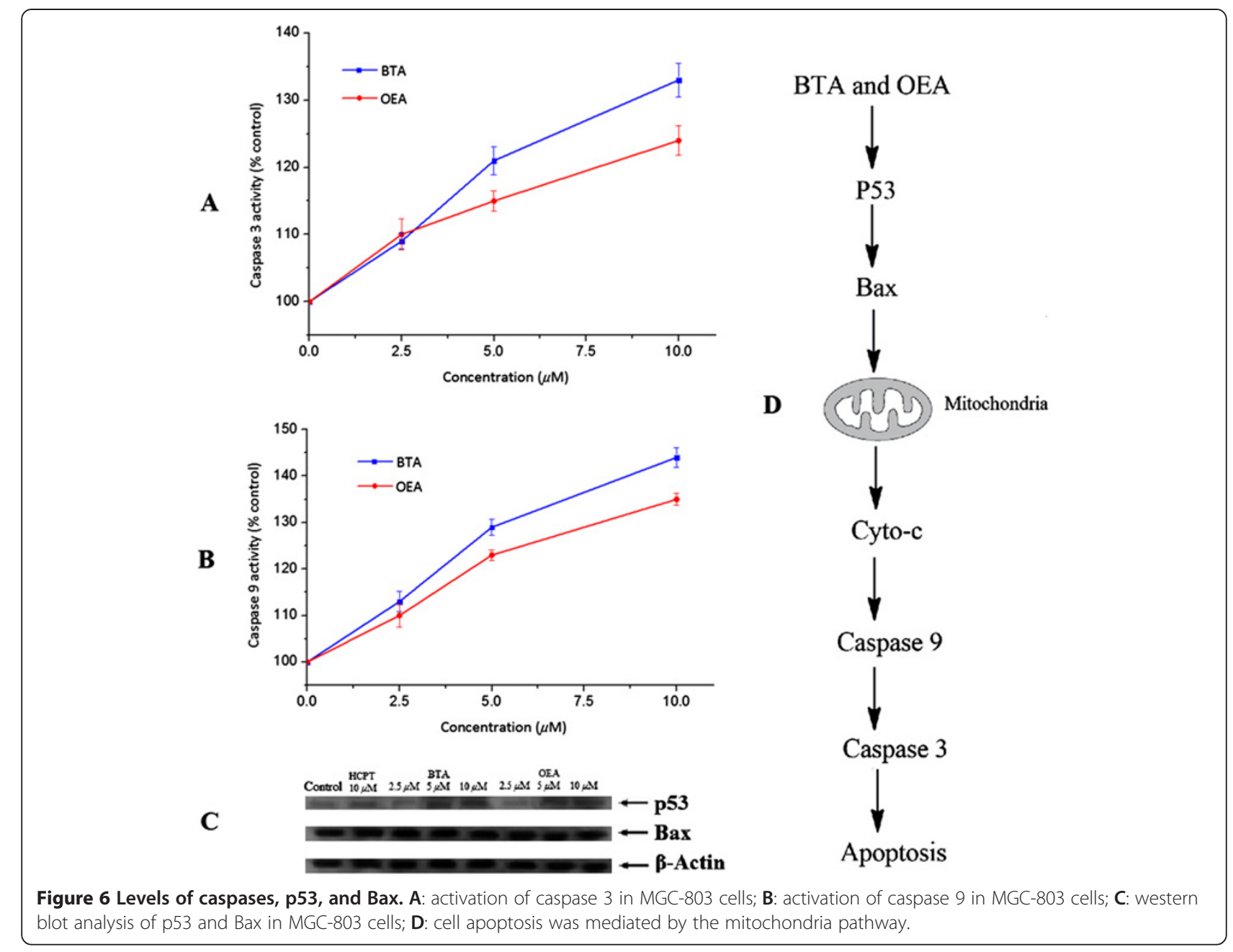

non-viable cells and emits red fluorescence by intercalation into DNA. Thus, live cells have a normal green nucleus, whereas the early apoptotic cells are bright green nucleus with condensed or fragmented chromatin and the late apoptotic cells display condensed and fragmented orange chromatin [35]. With HCPT as positive control, the BTA and OEA at $20 \mu \mathrm{M}$ for $24,48 \mathrm{~h}$ were detected via $\mathrm{AO} / \mathrm{EB}$ staining. As can be seen in Figure 2, early apoptotic cells with yellow dots and late apoptotic cells with orange dots in MGC-803 and PC3 cell nuclei in positive control, and the cells treated with BTA and OEA had changed. Yellow and orange dots in MGC-803 and PC3 cells showed early and late apoptotic cells, and the appearance of little red cells indicated that BTA and OEA were low cytotoxicity. Therefore, it can be concluded that BTA and OEA could induce apoptosis without any significant cytotoxicity.

Hoechst 33258 staining is used to visualize nuclear changes and apoptotic body formation that are characteristic of apoptosis. And it showed apoptosis in all four types of cells, which were characterized by cytoplasmic and nuclear shrinkage, chromatin condensation and apoptosis body [36]. With HCPT as positive control, the BTA and OEA at $20 \mu \mathrm{M}$ for $24,48 \mathrm{~h}$ were detected via Hoechst 33258 staining. As shown in Figure 3, cells treated with the negative control were normally blue. The cells of the negative group were normal blue. However, the HCPT group appeared compact condensed, and crescent-shaped. The cells exhibited strong blue fluorescence, revealing the typical apoptosis characteristics. The cells treated with BTA and OEA had changed, and cells nuclei appeared to be highly condensed and crescentshaped. These findings demonstrate that BTA and OEA could induce apoptosis against MGC-803 and PC3 cell lines, consistent with the results for the previous $\mathrm{AO} / \mathrm{EB}$ double staining.

In addition, TUNEL, one of the popular methods to investigate the apoptosis induction, identified apoptotic cells in situ via the detection of DNA fragmentation, due to the degradation of DNA after the activation of $\mathrm{Ca} / \mathrm{Mg}$-dependent endonucleases. This DNA cleavage 
leads to strand breaks within the DNA, and could be identified by terminal deoxynucleotidyl transferase that catalyzed the addition of biotin-dUTP. The biotin-labeled cleavage sites were then detected by reaction with streptavidin-HRP and visualized by diaminobenzidine, as indicated by a brown color [37]. With HCPT as positive control, the BTA and OEA at $20 \mu \mathrm{M}$ for $24,48 \mathrm{~h}$ were detected via TUNEL assay. As shown in Figure 4, the cells treated with BTA, OEA and HCPT appear as brown precipitates. Therefore, it can be further concluded that BTA and OEA could induced apoptosis in MGC-803 and PC3 cells. The results were identical with the previous experiment.

The apoptosis ratios induced by BTA and OEA in MGC-803 cells were quantitatively assessed by FCM. In early apoptotic cells, phosphatidylserine (PS) which distributed inside the lipid bilayer in the normal cells was transferred from the inside of the cell membrane to the outside. Annexin $\mathrm{V}, \mathrm{a} \mathrm{Ca}^{2+}$ dependent phospholipidbinding protein with a high affinity for PS, was used to detect early apoptotic cells. PI (Propidine Iodide) was a red fluorescent dye and stained cells that had lost membrane integrity. Cells stained with Annexin V-FITC and PI were classified as necrotic cells (the upper left quadrant; Annexin ${ }^{-} / \mathrm{PI}^{+}$), late apoptotic cells (the upper right quadrant; Annexin ${ }^{+} / \mathrm{PI}^{+}$), intact cells (the lower left quadrant; Annexin ${ }^{-} / \mathrm{PI}^{-}$) or early apoptotic cells (the lower right quadrant; Annexin ${ }^{+} / \mathrm{PI}^{-}$) [38]. As shown in Figure 5A, BTA and OEA could induce apoptosis in MGC803 cells. Apoptosis ratios (including the early and late apoptosis ratios) for BTA and OEA were obtained after 72 $\mathrm{h}$ of treatment at a concentration of $20 \mu \mathrm{M}$, with the highest apoptosis ratios being $27.3 \%$ and $24.5 \%$, respectively. Furthermore, as shown in Figure $5 \mathrm{~B}$, the apoptosis of MGC-803 cells which treated with BTA and OEA increased gradually in a time-dependent manner.

p53 could induce apoptosis after DNA damage in cancer cells [39], while the pro-apoptotic bcl-2 family member, Bax was a candidate mediator of p53-induced apoptosis [40]. The bcl-2 family divided into prosurvival members such as Bcl-2, Bcl-XL, Bcl-w, and CED 9 and pro-apoptotic members such as Bax, Bad, and Bid [41]. On this occasion, these opposing family members could heterodimerize and the relative ratio of the pro-survival vs. pro-apoptotic members may determine whether the cell lives or dies [42]. The antiapoptotic members appear to function by inhibiting the release of cytochrome $\mathrm{c}$ from the mitochondria or by inhibiting Apaf-1 directly [43]. Cytochrome c acts as a co-factor with ATP for the activation of Apaf-1 which then activates caspase 9, an "initiator caspase", and caspase 9 can then in turn activate caspase 3 [44]. As shown in Figure 6A, 6B, and 6C, when MGC-803 cells were treated with BTA and OEA at different concentrations after $12 \mathrm{~h}$, the caspase $3 / 9, \mathrm{p} 53$, and Bax were activated significantly. Thus, the results revealed that the BTA and OEA could induce mitochondria pathway mediated cell apoptosis in MGC-803 cell line (Figure 6D).

\section{Conclusions}

In conclusion, studies on the chemical constituents from Toona sinensis, and their biological activities have assumed significance for the rational development and utilization of this plant. In this study, fifteen compounds were isolated and identified. Meanwhile, the tumor cell growth inhibition effects of these constituents on MGC803, PC3, A549 and MCF-7 cells were carried out by MTT assay. Among these compounds, BTA and OEA, which were isolated from Toona sinensis, showed potent activities on MGC-803 and PC3 cell lines in a dosedependent manner. The $\mathrm{IC}_{50}$ values of BTA and OEA on MGC-803 and PC3 cells were determined to be $17.7 \mu \mathrm{M}$ and $13.6 \mu \mathrm{M}, 26.5 \mu \mathrm{M}$ and $21.9 \mu \mathrm{M}$, respectively, all of which were lower than that on NIH3T3 cells $\left(\mathrm{IC}_{50}>50 \mu \mathrm{M}\right)$. The apoptosis inducing activities of BTA and OEA on MGC-803 and PC3 cell lines were investigated through $\mathrm{AO} / \mathrm{EB}$ staining, Hoechst 33258 staining, and TUNEL assay. In addition, the apoptosis ratios induced by BTA and OEA caused apoptosis of MGC803 cells were quantitatively assessed by flow cytometry, with apoptosis ratios of $27.3 \%$ and $24.5 \%$ after $72 \mathrm{~h}$ of treatment at $20 \mu \mathrm{M}$, respectively. Interestingly, the BTA and OEA induced cell apoptosis through the mitochondrial pathway in MGC-803 cells. Our findings have implied that BTA and OEA has potential therapeutic value for treatment of cancer.

\section{Additional file}

Additional file 1: The extraction and purification process of the compounds from the plant and their NMR data.

\section{Competing interest}

The authors declare there are not any competing interests.

\section{Authors' contribution}

SY designed the experiments and carried out most of the bioassay experiments. QZ and HX took part in the compound structural elucidation and bioassay experiments. ML took part of the bioassay experiments. QZ and WX carried out some structure elucidation experiments. Prof. BS and Prof. SY are the co-corresponding authors for this work. All authors read and approved the final manuscript.

\section{Acknowledgements}

The authors wish to thank the National Key Program for Basic Research (Nos.2010CB126105, 2010CB134504), the National Natural Science Foundation of China (Nos. 21132003, 21172048), Guizhou Province S\&T Program (No. 20103052) for the financial support.

Received: 16 December 2012 Accepted: 4 February 2013

Published: 9 February 2013 


\section{References}

1. Demain AL, Vaishnav P: Natural products for cancer chemotherapy. Microb Biotechnol 2011, 4:687-699.

2. Massaoka MH, Matsuo AL, Figueiredo CR, Farias CF, Girola N, Arruda DC, Scutti JAB, Romoff P, Favero OA, Ferreira MJP, Lago JHG, Travassos LR: Jacaranone induces apoptosis in melanoma cells via ROS-mediated downregulation of Akt and p38 MAPK activation and displays antitumor activity in vivo. PLoS One 2012, 7:1-11.

3. Patel B, Sattwik das, Prakash R, Yasir M: Natural bioactive compound with anticancer potential. Int J Adv Pharm Sci 2010, 1:32-41.

4. Cragg GM, Newman J: Nature: a vital source of leads for anticancer drug development. Phytochem Rev 2009, 8:313-331.

5. Cragg GM, Newman J: Plants as a source of anti-cancer and anti-HIV agents. Ann Appl Biol 2003, 143:127-133.

6. Nobili S, Lippi D, Witort E, Donnini M, Bausi L, Mini E, Capaccioli S: Natural compounds for cancer treatment and prevention. Pharmacol Res 2009, 59:365-378.

7. Fulda S, Debatin KM: Sensitization for tumor necrosis factor-related apoptosis-inducing ligand-induced apoptosis by the chemopreventive agent resveratrol. Cancer Res 2004, 64:337-346.

8. Fulda S: Modulation of apoptosis by natural products for cancer therapy. Planta Med 2010, 76:1075-1079.

9. Solary E, Droin N, Bettaieb A, Corcos L, Dimanche-Boitrel MT, Garrido C: Positive and negative regulation of apoptotic pathways by cytotoxic agents in hematological malignancies. Leukemia 2000, 14:1833-1849.

10. Castellanos L, Correa RS, Martinez E, Calderon JS: Oleanane triterpenoids from Cedrela montana (Meliaceae). Z Naturforsch C 2002, 57:575-578.

11. Kommera H, Kalud-erovic'GN, Dittrich S, Kalbitz J, Dräger B, Mueller T, Paschke R: Carbamate derivatives of betulinic acid and betulin with selective cytotoxic activity. Bioorg Med Chem Lett 2010, 20:3409-3412.

12. Rao VS, de Melo CL, Queiroz MGR, Lemos TLG, Menezes DB, Melo TS, Santos FA: Ursolic acid, a pentacyclic triterpene from Sambucus australis, prevents abdominal adiposity in mice fed a high-fat diet. J Med Food 2011, 14:1375-1382

13. Ryu SY, Choi SU, Lee SH, Lee CO, No Z, Ahn JW: Antitumor triterpenes from medicinal plants. Arch Pharm Res 1994, 17:375-377.

14. Cichewicz RH, Kouzi SA: Chemistry, biological activity, and chemotherapeutic potential of betulinic acid for the prevention and treatment of cancer and HIV infection. Med Res Rev 2004, 24:90-114.

15. Chintharlapalli S, Papineni S, Lei P, Pathi S, Safe S: Betulinic acid inhibits colon cancer cell and tumor growth and induces proteasomedependent and -independent downregulation of specificity proteins (Sp) transcription factors. BMC Cancer 2011, 11:371-383.

16. Fulda S: Betulinic acid for cancer treatment and prevention. Int J Mol SC 2008, 9:1096-1107.

17. Pisha E, Chai H, Lee IS, Chagwedera TE, Farnsworth NR, Cordell GA, Beecher CW, Fong HH, Kinghorn AD, Brown DM: Discovery of betulinic acid as a selective inhibitor of human melanoma that functions by induction of apoptosis. Nat Med 1995, 1:1046-1051.

18. Min BS, Kim YH, Lee SM, Jung HJ, Lee JS, Na MK, Lee CO, Lee JP, Bae K: Cytotoxic Triterpenes from Crataegus pinnatifida. Arch Pharm Res 2000 23:155-158

19. Ma CM, Cai SQ, Cui JR, Wang RQ, Tu PF, Hattori M, Daneshtalab M: The cytotoxic activity of ursolic acid derivatives. Eur J Med Chem 2005, 40:582-589.

20. Kim DK, Baek JH, Kang CM, Yoo MA, Sung JW, Chung HY, Kim ND, Choi YH, Lee SH, Kim KW: Apoptotic activity of ursolic acid may correlate with the inhibition of initiation of DNA replication. Int J Cancer 2000, 87:629-836.

21. Andersson D, Liu JJ, Nilsson A, Duan RD: Ursolic acid inhibits proliferation and stimulates apoptosis in HT29 cells following activation of alkaline sphingomyelinase. Anticancer Res 2003, 23:3317-3322.

22. Zhang $X$, Li H, Jin Y, Fang G: Effects of betulonic acid on SGC-7901, HepG-2 and mice of bearing S180 tumor cells. Nat Prod Res Dev 2009, 21:766-770.

23. Saxena BB, Zhu L, Hao M, Kisilis E, Katdare M, Oktem O, Bomshteyna A, Rathnam P: Boc-lysinated-betulonic acid: a potent, anti-prostate cancer agent. Bioorg Med Chem 2006, 14:6349-6358.

24. Guo L, Wu JZ, Han T, Cao T: Chemical composition, antifugal and antitumor properties of ether extracts of Scapania verrucosa Heeg. and its endophytic fungus Chaetomium fusiforme. Molecules 2008, 13:2114-2125
25. Dellai A, Deghrigue M, Laroche-Clary A, Masour HB, Chouchane N, Robert J, Bouraoui A: Evaluation of antiproliferative and anti-inflammatory activities of methanol extract and its fractions from the Mediterranean sponge. Cancer Cell Int 2012, 12:18.

26. Kjellström J, Oredsson SM, Wennerberg J: Increased toxicity of a trinuclear Pt-compound in a human squamous carcinoma cell line by polyamine depletion. Cancer Cell Int 2012, 12:20.

27. Wei HB, Hu BG, Han XY, Zheng ZH, Wei B, Huang JL: Effect of all-trans retinoic acid on drug sensitivity and expression of survivin in LoVo cells. Chin Med J 2008, 4:331-335.

28. Jiang Z, Wu W, Qian M: Cellular damage and apoptosis along with changes in NF-kappa B expression were induced with contrast agent enhanced ultrasound in gastric cancer cells and hepatoma cells. Cancer Cell Int 2012, 12:8.

29. Holmquist G: Hoechst 33258 fluorescent staining of Drosophila chromosomes. Chromosoma 1975, 49:333-356.

30. Liu MC, Yang SJ, Jin LH, Hu DY, Wu ZB, Yang S: Chemical constituents of the ethyl acetate extract of Belamcanda chinensis (L.) DC roots and their antitumor activities. Molecules 2012, 5:6156-6169.

31. Orozco AF, Lewis DE: Flow cytometric analysis of circulating microparticles in plasma. Cytom A 2010, 77:502-514.

32. Ishikawa J, Takahashi Y, Hazawa M, Fukushi Y, Yoshizawa A, Kashiwakura I: Suppressive effects of liquid crystal compounds on the growth of U937 human leukemic monocyte lymphoma cells. Cancer Cell Int 2012, 12:3.

33. Liu J, Uematsu H, Tsuchida N, Ikeda MA: Essential role of caspase-8 in p53/ p73-dependent apoptosis induced by etoposide in head and neck carcinoma cells. Mol Cancer 2011, 10:1-13.

34. Collins JA, Schandl CA, Young KK, Vesely J, Willingham MC: Major DNA fragmentation is a late event in apoptosis. J Histochem Cytochem 1997, 45:923-934

35. Liu MC, Yang SJ, Jin LH, Hu DY, Xue W, Song BA, Yang S: Synthesis and cytotoxicity of novel ursolic acid derivatives containing an acyl piperazine moiety. Eur J Med Chem 2012, 58:128-135.

36. Wu J, Yi WS, Jin LH, Hu DY, Song BA: Antiproliferative and cell apoptosisinducing activities of compounds from Buddleja davidii in MGC-803 cells. Cell Div 2012, 7:1-20.

37. Xu XQ Gao XH, Jin LH, Yuan K, Hu DY, Song BA, Yang S: Antiproliferation and cell apoptosis inducing bioactivities of constituents from Dysosma versipellis in PC3 and Bcap-37 cell lines. Cell Div 2011, 6:1-14.

38. Yuan $\mathrm{K}$, Song $\mathrm{BA}$, Jin $\mathrm{LH}, X u \mathrm{~S}, \mathrm{Hu} \mathrm{DY}, \mathrm{Xu} X \mathrm{X}$, Yang S: Synthesis and biological evaluation of novel 1-aryl, 5-(phenoxy-substituted) aryl-1,4pentadien-3-one derivatives. Med Chem Commn 2011, 2:585-589.

39. Cui H, Schroering A, Ding HF: p53 mediates DNA damaging drug-induced apoptosis through a caspase-9-dependent pathway in SH-SY5Y neuroblastoma cells. Mol Cancer Ther 2002, 1:679-686.

40. Juin P, Hunt A, Littlewood T, Griffiths B, Swigart BL, Korsmeyer S, Evan G: c Myc functionally cooperates with Bax to induce apoptosis. Mol Cell Biol 2002, 22:6158-6169.

41. Brunelle JK, Letai $\mathrm{A}$ : Control of mitochondrial apoptosis by the $\mathrm{BCl}-2$ family. J Cell Sci 2009, 122:437-441.

42. Basu A, Haldar S: The relationship between Bcl2, Bax and p53: consequences for cell cycle progression and cell death. Mol Hum Reprod 1998, 1998:1099-1109.

43. Gross $\mathrm{A}$, McDonnell JM, Korsmeyer SJ: BCL-2 family members and the mitochondria in apoptosis. Gene Dev 1999, 13:1899-1911.

44. Rodriguez J, Lazebnik Y: Caspase-9 and APAF-1 form an active holoenzyme. Gene Dev 1999, 13:3179-3184.

doi:10.1186/1475-2867-13-12

Cite this article as: Yang et al:: Antiproliferative activity and apoptosisinducing mechanism of constituents from Toona sinensis on human cancer cells. Cancer Cell International 2013 13:12. 